

\title{
Transnational identity claims, roles and strategic foreign policy narratives in the Middle East
}

\author{
Edward Wastnidge, edward.wastnidge@open.ac.uk
}

\begin{abstract}
The question of identity, not only framed within the context of the nation state, but also in terms of wider transnational identities, be they religious, ethnic or political, remains a key feature in the politics of the Middle East. Drawing on contributions from Foreign Policy Analysis and the concept of strategic narrative, this paper explores how identities beyond state borders are utilised as justification for a state's foreign policy decisions. The states under investigation are Turkey and Iran. The paper shows how appeals to transnational identities have been used by each state in terms of their longer-term cultural diplomacy and 'soft power' initiatives, and then at the more immediate or 'hard' sense as seen in their recent, ongoing military engagements. It demonstrates how multiple and overlapping identities articulated at the transnational level serve as a vector in which to pursue strategic foreign policy narratives in each country's perceived sphere of influence.
\end{abstract}

\section{Introduction}

This paper stems from a desire to revisit, expand on and, to a certain extent, update studies of Middle Eastern states' foreign policies and to re-assess the question of identity and what it means in the study of the region's international relations. This comes at a time when the region is subject to considerable tumult following the stalling of the Arab Uprisings and rise of non-state and sub-state entities that seek to challenge the existing order. This has opened up new spaces for identity claims, which some states have sought to make use of - drawing on cultural reference points that have at times become magnified as states' strategic and political imperatives take advantage of sectarian and ethnic divisions. The question of identity not only framed within the context of the nation state, but also in terms of wider transnational identities, be they religious, ethnic or indeed political, remains a key feature in the politics of the Middle East. It may not be the sole driver of conflict or cooperation, 
but it acts an important justification for states' actions as the two case studies in this paper demonstrate. The states under investigation are Turkey and Iran. The paper demonstrates how foreign policy in both states is often formed around transnational identity claims, based on their positions as core metropoles for wider identities that reach beyond their borders. Within the case studies examined here, one can observe complex networks made up of multifaceted identity linkages that serve both states' foreign policy objectives.

This is a study based on identities - at times competing, at others complimentary - and it explores how the existence of ethnic or religious groups in another state are utilised to define a foreign policy narrative which provides subsequent justification for a state's foreign policy course. As such it makes use of contributions from a range of literature across International Relations (IR), Foreign Policy Analysis (FPA) and Area Studies as a means of assessing the preponderance of identity-based narratives in these two key regional states' foreign policy actions. It acknowledges the valued contribution from scholars working on role theory-based analyses in FPA tradition and constructivist IR theory, while also drawing on insight from recent work on the notion strategic narratives in International Relations. It builds on Hudson's (2014: 119) 'who are we, what do we do, who are they?' framework for tying identity to foreign policy by demonstrating that a 'how are they like us?' type question is also utilised by the states in question as a means of cultivating networks with certain groups in other states for cultural diplomacy and other initiatives. The subsequent enquiry from this is then based around illustrating how both states define their roles and articulate them through the development of a 'strategic foreign policy narrative'. It therefore seeks to demonstrate how multiple and overlapping identities articulated at the transnational level serve as a vector in which to pursue strategic foreign policy narratives in each country's perceived sphere of influence.

The paper examines Turkey and Iran as two key powers who have in recent years had some of the most activist foreign policies in the region and beyond. For both examples we can see clear foreign policy actions that are based on important identity factors that are actually found in other states. Often these are used as a reinforcing or legitimating tool 'back home' to appeal to their respective core domestic constituencies, and so chimes with Barnett's (2002: 63) assertion that identity makes some foreign policy actions legitimate and intelligible. These countries stand as two key, non-Arab powers, in a region where there have been competing transnational identity claims, in the form of pan-Arabism, and a pan-Islamism based on Saudi largesse. Here we see two contrasting states with different conceptions of the region and their roles in it, and with different systems of government - a democracy (with some recent authoritarian tendencies), and a quasi-democratic theocracy. However, a common theme is their use of identity politics in shaping their foreign policies. Breuning's (1997) work on comparing Dutch and Belgian foreign policies vis-à-vis their own cultural values is illustrative of how culture and identity discourses can affect foreign policy outcomes in different ways. Similarly, in this paper one can observe how both states draw on historical and cultural reference points, which result in a similar utilisation and cultivation of networks among specific groups and/or states. While the action and rationale may be similar, they naturally result in different foreign policies, due to their differing cultural reference points. Both states analysed in this study have a long history of using identities in other states as a reinforcing, legitimating device for justifying their foreign policy actions, and this paper will outline how these are used as to develop a strategic foreign policy narrative and inform subsequent action. 
By way of structure, the paper begins by setting out a combination of identity-led FPA and the concept of 'strategic narratives' as an explanatory framework. The framework helps to shed light on how Iran and Turkey communicate a role that is based on certain identity-based attributes, and they have sought to craft a foreign policy role and articulate this through a strategic narrative based on a transnational identity with each of them at its core. This will be followed by the two empirical test cases which explore how identity-based foreign policy roles are realised in Turkey and Iran. The analysis of the two case studies is bifurcated for heuristic purposes. Within each, I firstly illustrate how identity forms a key plank of each state's cultural diplomacy and soft power strategies, before moving on to demonstrate its continued salience in their military engagements in the region.

\section{Foreign policy analysis: Identities, roles and strategic narratives}

By means of a summary of how FPA serves as a useful framework, the leading FPA scholar Valerie Hudson (2005: 10) argues that 'Culture, history, geography, economics, political institutions, ideology, demographics, and innumerable other factors shape the societal context in which the decision maker operates'. Expanding further, she sees studies into how culture and issues of identity affect foreign policy choice as being one of the least developed areas of the sub-field (Hudson, 2014: 118). Using a 'who are we, what do we do, who are they' framework for tying identity to foreign policy, Hudson (2014: 119) explains how conceptions of others are often different from their own self-conceptions. This is interesting for this paper because it is a question that can be applied to the case studies but it takes it a step further by asking a 'how are they like us?' type question as a means of cultivating certain networks as recipients for cultural diplomacy and other initiatives. In the foreign policy initiatives of the two states examined below, we see a culture-foreign policy interface made up of shared, evolving meaning conditioned by historical precedent and contemporary experience (Hudson, 2014: 125).

A form of national role conception is also useful to note at this point, in so far as state leaders articulate a vision of their nation's role in world affairs which corresponds to deep cultural beliefs about their nation (Hudson, 2014: 130). The idea of national role conceptions has been a part of FPA since Holsti's, (1970) seminal work of the same title. The roles defined by Holsti, (1970) include 'mediator', 'regional leader', 'bridge', 'bastion of the revolution', 'defender of the faith' among others and while they were written in a Cold War context they remain salient today, particularly with regards to Turkey and Iran. The very images and identity of the state that its leader (and by extension its foreign policy and diplomatic apparatus) holds go on to shape the way in which it acts internationally. As such, the roles that a state conceives for itself says much about a country's identity, its priorities and policies, and how it relates to other states (Cantir and Kaarbo, 2012: 19). Thies (2010) notes how role theory is used in FPA at various levels (namely individual, state, and system level analyses). The transnational emphasis in this paper in relation to Iran and Turkey provides us with an interesting mid-way between state and system level analysis, thus moving it towards constructivist thinking found within IR scholarship, but with an acknowledgement of how identity informs foreign policy roles in the space between state and system-led explanations. 
Constructivists see identities as forming the basis of interests (Wendt, 1992: 398). Consequently, foreign policy behaviour is determined by domestic politics, which Wendt sees as being analogous to individual personality rather than being shaped by the international system (Wendt, 1999: 2). Thus, in Wendt's work a certain degree of anthropomorphisation takes place. Such an approach brings theory and practice close together, as within such a framework the role of ideas assumes greater prominence in foreign policy thinking. Therefore, the role of agency can be seen as crucial to states' behaviour in so far as government action may be based on identity factors that in turn generate and shape interests, rather than the converse position of structural-(neo)realist thinking.

Although there is recognition of the need for greater empirical analyses to demonstrate the importance of culture and identity to IR, and indeed foreign policy, there is still a tendency within constructivism to talk about such identities and culture in an abstract way. While such concepts are by their very nature abstractions of a perceived reality, and a certain degree of reification inevitably takes place, there is a tendency in some IR scholarship to use identity as a referent object, but not to pursue those features that are intrinsic to it. Thus, despite attempts to increase awareness of cultural factors and identity, they remain as something of a 'given', and are still not explored in enough detail. As Barnett, (1999) argues, constructivism's focus on ideas and culture means that there is insufficient attention given to the agency of actors within a strategic context. However, one could argue that this is understandable due to the very nature of IR as a discipline which seeks to examine systemic as opposed to state-specific issues of foreign policy.

The foreign policy roles that states assume are social constructs and rationalist cognitive concepts (Harnisch et al, 2011: 2). To this end they are reflections of the social order that a state is living in, and the social stratification of world politics reflects tensions within those role conceptions (Harnisch, 2011: 15). There is therefore great value in taking up the call to use insight from role theory as a tool for bridging the gap between FPA and IR (see Thies, 2010; Cantir and Kaarbo, 2012; Thies and Breuning, 2012). Indeed Breuning (2011: 20) has argued that role theory is implicit in constructivist thinking, noting how authors who 'grapple with norms, identity, self-image' use langue that is close to the idea of role conceptions.

While cognisant of the tendency of role theory-based analyses to focus primarily on foreign policy making elites (Cantir and Kaarbo, 2012: 19), it is useful in the cases examined in this paper as it is about government elites that are the main generators of foreign policy. Hence there is a certain degree of unitary actor assumption, or what Cantir and Kaarbo (2016: 8-9) describe as 'black-boxing' of elites in the following case studies. That said, some contestation is arguably present in both cases examined here, in terms of disconnect between the people and ruling regimes, what Cantir and Kaarbo (2016: 9-11, 174-7) would term 'vertical contestation', and also intra-elite disagreement, or 'horizontal contestation' (Cantir and Kaarbo, 2016: 11-16, 177-81). Regarding the latter, in Iran one can observe potential tensions between the popularly elected government versus the views of the Supreme Leader and the powerful Islamic Revolutionary Guards Corps. ${ }^{1}$ While in Turkey, this can be seen in the historic tension between sections of the Army versus the government - particularly in light of the 2016 coup attempt there. However, both states aspire to be regional leaders, while also perceiving themselves as centres for wider, cultural affinities, be they religious, ethnic or both. These are identity claims 
that go beyond the borders of the nation state, thus challenging fixed spatially defined notions of identity and also state power and sovereignty. Transnational identity is fixed on idea of each state acting as a metropole for the wider identity that it is promoting and using. Therefore, the foreign policy role is one of acting as the ethnic and/or religious core, and therefore 'guide' to the groups and/or states that are targeted by their foreign policies.

While not offering a test case for role theory analysis per se, this paper argues that foreign policy roles in Turkey and Iran are often made with reference to shared identities that reach beyond their borders, utilising identity claims based on common cultural heritage. It is such identities which create norms that shape foreign policy behaviour as they form a key part of a state's national interests (Barnett, 1995; 1996: 2002; Telhami and Barnett, 2002). It agrees with Hudson's (1999) argument that a state's cultural heritage is key to its national role conception. National role conceptions are closely tied to concepts such as identity, self-image and norms (Breuning, 2011: 22-3), and these are shaped into a narrative for their respective foreign policy choices. These narratives are important because there are multiple narratives in which a state engages, and which correspond to narrative identities about how a state sees itself (Miskimmon et al, 2013: 32-3).

The question that stems from this kind of approach is how are these states defining and enacting their roles? The answer lies in the identity narratives that they are communicating, and it is this which explains why these transnational linkages are drawn on. The public diplomacy enacted by Turkey and Iran can be understood through Miskimmon et al's (2013) concept of 'strategic narratives', which sits at the intersection of IR and communication studies. Strategic narratives are

a tool for political actors to extend their influence, manage expectations, and change the environment in which they operate. They are narratives about both states and the system itself, both about who we are and what kind of order we want. (Miskimmon et al, 2013:2)

Such narratives are usefully typologised via three different levels, namely 'system narratives' (referring to the way that the international system is structured), 'identity narratives' (regarding the contested identity of actors/nations in international affairs), and 'issue narratives' (concerning why a policy is needed and how it might be implemented) (Miskimmon et al, 2013: 2). As Roselle et al (2014: 74) note in their subsequent iteration of strategic narratives vis-à-vis the notion of soft power, a compelling narrative can be a power resource in its own right, as people may be drawn to certain actors, events, and explanations that describe the history of a country, or the specifics of a policy, for example. It is the second level, that of identity narratives, which are of particular interest in this study, because they help set out and define what a state's goals are (Roselle et al, 2014: 76). Here, the authors build on the work of scholars using role theory analysis (Walker, 1987; Holsti, 1970; Thies, 2012a; 2012b) in showing that such narratives act as power resources in their own right. Strategic narratives represent identities and act as a tool by which political actors - primarily elites - give meaning to past present and future in order to achieve their political objectives (Miskimmon et al, 2013: 5). The cases presented below take this a step further by illustrating how the foreign policy roles developed by Turkey 
and Iran take note of transnational identities, which are then shaped into strategic foreign policy narratives.

Identity considerations, be they shared or differentiated, are useful from a public diplomacy point of view as they give a strong hook on which to hand a state's foreign policy actions and provide justification and legitimation domestically. The work on strategic narratives also represents a valuable recent contribution to the existing literature on soft power. It has taken it from being something of a given in studies of foreign policy behaviours, focusing on the counting of soft power assets and capabilities, to a more nuanced idea that looks at how such ideas and narratives are communicated. Also, the distinction between soft and hard power is not always clear. In contrast to Nye's (2004) well known formulation of soft power being the co-optive opposite to the hard power of 'coercion', Mattern (2005: 584) has argued that there is a certain degree of coercion present. This is because a state's soft power success will ultimately depend on knowing how exactly to make their idea and themselves attractive to a target population.

Miskimmon et al (2013: 32) explain that 'Narratives set out who the actors are, what characterises them, what attributes they possess, what actions they take, and what motivates them.' The states examined below are the key actors in communicating a role that is based on certain identity-based attributes. Narratives of shared identity are not simply used for principled reasons, but also for pragmatic and strategic ones (Barnett, 2002: 68). There is an inherent strategic focus in the way that Iran and Turkey have sought to incorporate identity into their foreign policies, and articulate this through a strategic narrative based on a transnational identity with each of them at its core.

\section{The International Relations of the Middle East: Some exemplary voices}

Those familiar with the academic study of the international relations of the Middle East will be aware of the esteemed contributions of Raymond Hinnebusch, Michael Barnett, Louise Fawcett and Fred Halliday, among others. The following brief survey does scant justice to their efforts, but is useful in helping delineate the varied analytical frameworks and intellectual heritages that have shaped the study of the region. Needless to say, it is those who synthesise elements of different traditions that provide the most useful analytical frameworks. This kind of approach avoids the narrow discipline-specific foci that does not always fully illuminate or provide explanation of how the region can be best understood. For example, an approach that might draw purely on the intellectual traditions of IR has the familiar problem of the overarching dominance of IR theory within the discipline, with its attendant focus on systemic elements. This can lead to difficulty in explaining relations between specific states. One can note the effect of outside powers, core-periphery, and colonial/post-colonial arguments - but the two, longstanding independent nations of Turkey and Iran presented in this paper have considerable agency within the region and beyond in their own right.

With its modified form of realism providing the framework, Hinnebusch and Ehteshami's (2014) The Foreign Policies of Middle East States provides a classic piece of analysis on the region's key states. For Hinnebusch (2014: 1), states remain the key actors and maximising the autonomy and security of the state is key. Foreign policy role is especially important - the identity it is based on defines orientation towards neighbours. For Hinnebusch (2014), the incongruity between state and identity in 
the region is perhaps its most distinctive feature. With reference to pan-Arabism, he notes how loyalty to the state is contested by a suprastate identity that often drive competition for regional leadership. Writing in 2005, Louise Fawcett emphasised the importance of the state, cautioning against overstating the transnational or sub-national case, pointing to the durability of the state system in the Middle East (Fawcett, 2005: 2-3). This remains largely true, and while that durability has been challenged more in recent years, it is still states that this paper also uses as its key reference point, but with an acknowledgement that appeals to transnational identities constitute a core determinant of foreign policy making.

Telhami and Barnett (2002: 1-25) and Barnett (1996: 400-47) apply constructivist IR in their analysis of identity and foreign policy in the Middle East. Their focus on contested state and national identities evidences the importance of the sub-national in foreign policy, especially in multi-ethnic states such as Iran and Turkey. The interplay between identity and foreign policy, and also the relationship between ideational and strategic considerations is perhaps best captured by Barnett's (1996: 400-47) treatment of identity in alliance formation among the Arab states of the Middle East. In examining the Gulf Cooperation Council (GCC), in whose formation Iran was clearly a key factor, he states

In short, while strategic factors were certainly part of the story behind the GCC and the response to perceived internal and external security threats, identity was a critical factor in shaping the definition of the threat and the alliance response. (Barnett, 1996: 428)

As a counter to the constructivist argument, Shaffer (2006a: 1-26; 2006b: 219-40) has sought to emphasise how culture and identity are often overstated in discussion of foreign policy, using Iran as an example of a state that places pragmatism over ideology. However, with Iran Shaffer tends to focus primarily on Islam as the defining feature of Iranian cultural identity, focusing as she does on the Islamic Republic. In this sense it is easy to agree with her contention as Iran has often placed national interest over ideological concerns; however, this is not new in Iranian FPA (see Ehteshami and Varasteh, 1991; Calabrase, 1994; Ramazani, 1992; 2004). In adopting this focus Shaffer ignores the clearly ideational slant of successive Iranian foreign policies, both in terms of specific identity promulgations, and key themes such as justice and countering oppression, that remains prevalent despite changing governments. Conversely, Ansari (2006: 243) gives a more nuanced treatment of Iran's foreign policy in the same volume, arguing for 'an acceptance of the importance of cultural determinants in conjunction with material interests'. Stein (2012) has also questioned utility of constructivist interpretations for understanding the international politics of the Middle East. In a counter to the constructivist take offered by Barnett, he notes the problem of perceiving of Arabism as a constitutive part of the region international relations as articulated by constructivist takes on Middle Eastern politics.

Perhaps the most influential text on this paper, in terms of its combination of approaches, is the late Fred Halliday's (2005) The Middle East in International Relations. Noting how the realist focus on states alone can run the risk of ignoring key formative processes (Halliday, 2005: 28), he adopts an approach that fuses insight from historical sociology with FPA to explain the international relations and foreign policy making of Middle Eastern states. He argues that 'Foreign policy is, certainly, not only an activity 
which states have to justify, not least because of the costs involved, but also one that serves, or should serve, to justify the state to its own population' (Halliday, 2005: 48). This is why we see a use of identity, whether it be common or irredentist notions, as justification and vector for foreign policies. Self-image is therefore important in determining relations between states as this paper demonstrates. By adopting an FPA approach, the analysis goes beyond the category of the state as political or legal boxes, and as such they can be seen as 'the objects of diverse, often conflicting forces from within and without' (Halliday, 2005: 27). This paper seeks to add to this rich scholarly tradition in Area Studies by providing a new framework for understanding the role of identity in regional politics, as illustrated by the following case studies.

\section{Turkey}

Turkey is a key regional state. Its position as a partner of the West in NATO, geostrategic location, and its civilisational inheritance, both in terms of being the heir to the Ottoman Empire and perceived 'leader' or guide of the Turkic world, attest to its importance. When considering how identity considerations influence Turkey's foreign policy, one can explore self-image factors as a key influence in light of its democracy and the ability of various groups to influence course of government and subsequently its foreign policy (Seufert, 2012). But for this paper, the focus is on the importance of foreign policy actions as determined by external but common identity factors that have a resonance internally.

At the first level, in terms of Turkey's longstanding cultural diplomacy initiatives, one can observe a strong national role conception that shaped its foreign policy through the first part of the post-Cold War period. This found a manifestation in the role of Turkey as model for the newly independent states of Central Asia and Azerbaijan, which can be seen as an attempt at a kind of pragmatic pan-Turkism. Turkey was keen to sponsor and set up regional groupings that drew on its perceived common cultural heritage. An example of this can be seen in the establishment in 1993 of the International Organization of Turkic Culture (TÜRKSOY), set up by Turkey to "strengthen the ties of brotherhood and solidarity among Turkic peoples and transmit their cultural heritage to future generations. ${ }^{2}$ Despite the talk in the 1990s of possible completion between Turkey, Russia and Iran in Central Asia (Peimani, 1998; Raekel, 2003), Turkish political and economic penetration was limited, with the sense that the Turkish government would be overstretching itself if it seriously pursued a regional leadership role there (Kassimeris, 2010: 332). However, TÜRKSOY remains an important plank of Turkey's cultural diplomacy and it continues to use its perceived position as the cultural centre of the Turkish world to promote educational cooperation and cultural links with the Turkic world (Akcalı and Engin-Demir, 2012). In 2007, the Turkish government also established the Yunus Emre foundation, charged with setting up Turkish cultural centres worldwide. ${ }^{3}$ While the centres have a key role for existing Turkish expat communities beyond Turkey's borders, they also act as an important platform for the promotion of Turkish identity abroad (Kaya, 2013: 55-60). Thus, cultural links are drawn on, both in terms of targeting Turkic populations as a venue for cultural diplomacy, and also in providing a presence for Turkish citizens living abroad.

The establishment of such centres can be seen as an illustrative example of the public diplomacy carried out by the Justice and Development Party (AKP) since its 
election in 2003. AKP foreign policy has been subject to numerous analyses over the last decade or so, as Turkish politics was seen as turning away from its Kemalist, avowedly secular orientation to an Islamist-inspired outlook. Turkey's traditional foreign policies have generally been based around the core roles of 'defender of peace and stability', 'regional system collaborator' and 'global system collaborator' (Özdamar, 2016: 90). The term 'neo-Ottoman' has been a common phrase used to describe a perceived reorientation towards the Middle East and wider Muslim world in numerous academic and commentary pieces (see Taşpinar, 2008; Kaya, 2013; Kiper, 2013; Öztürk, 2013; Arin, 2014; Danforth, 2014). However, this is a problematic term as the concept itself lacks any true definition, being subject to a range of typologies that render its analytical utility questionable. The conceptual contestability and imprecision of neo-Ottomanism contributes to its limited analytical and explanatory value in a foreign policy milieu, but arguably a more precisely delineated neo-Ottomanism as a rhetorical and legitimating framework can be usefully applied to the AKP's domestic policies, particularly when one observes the utilisation of Ottoman symbolism and reference points there (Wastnidge, 2019). Rather than talk about a vague and seemingly amorphous neo-Ottomanism at the foreign policy level, it is better to perhaps conceive this as an engagement with previously-ruled Ottoman territories, what Bilgin (2015) terms as a kind of former 'Ottoman geopolitical space', by the AKP. Hence, it is an emphasis on shared culture and historical experience that drives this foreign policy, devoid of the explicit Ottoman references seen at the domestic level, rather than any explicit neo-imperial agenda.

However, there remains a strong identity current that shapes Turkish foreign policy under the AKP. This found itself articulated through the works and subsequent actions of former Foreign Minister and, until recently, Prime Minister Ahmet Davutoğlu. Davutoğlu (2001) sees Turkey as a central country and seeks to make use of its historical and geographical inheritance to further its position in world politics, drawing on his work as an IR scholar prior to taking office. Davutoğlu seeks a leadership role in the Muslim world for Turkey, framed by a desire to transform Turkey into a legitimate alternative power centre, as the leader and ultimate representative of a distinct civilisation (Arkan and Kınacıoğlu, 2016: 389). To this end, Turkish identity is portrayed through its foreign policy as forming a distinctive identity, with a unique history and geography, 'that holds a singular place as the global representative, speaker and leader of a specific community of peoples' (Arkan and Kınacıoğlu, 2016: 383). This interpretation sits within the 'identity narrative' level identified by Miskimmon et al (2013), taking the form of a Turkish-Islamist identity narrative that drives the AKP foreign policy, with its attendant foci on the wider Muslim world (of which fellow Turkic nations form an indelible part) and an acknowledgement of the power of public diplomacy. Indeed, Turkey created a dedicated office of public diplomacy in 2010 to 'tell its story' (Ennis and Momani, 2013: 1128), part of which was promoting the 'Turkish model' post-Arab Uprisings. The identity-based narrative and public diplomacy efforts of Turkey in recent years has manifested itself in what many scholars of Turkish foreign policy have deemed as a form of soft power projection (see Oğuzlu, 2007; Davutoğlu, 2010; Batalla-Adam, 2012; İpek, 2015). As with the neo-Ottoman label, the application of soft power is open to wide interpretation, but variously this has included acting as a democratic model, an economic partner, a provider of development assistance, and a prominent actor in global public diplomacy, with a specific focus on the Muslim world. Prior to the attempted coup against the 
government of Recep Tayyip Erdoğan in 2016, Turkish soft power projection was also aided by the global network of schools affiliated to the now-exiled Turkish cleric and alleged inspiration behind the coup attempt, Fethullah Gülen. According to Balc1 (2014), the network of schools was 'often more successful at spreading the tenets of Turkishness, such as the Turkish language and culture, than educational initiatives sponsored by the Turkish government itself'. Since 2016 the Turkish government has sought to gain control of these schools (von Schwerin, 2018) as a means of limiting the influence of the network and seizing control of the what was once a key lever of Turkish soft power.

Under the AKP Turkey has also fostered political links with the Muslim Brotherhood across the Middle East, seeking to act as a role model for modern Islamic politics. This has also helped cement an alliance with another key patron of the Brotherhood, Qatar, which is currently acting as an alternative axis to the other conservative monarchies of the Persian Gulf, namely Saudi Arabia and the United Arab Emirates (UAE). The political and security cooperation between the two states has subsequently deepened as a result of the continuing blockade of Qatar by the GCC and Egypt, and the extra-territorial killing of Jamal Khashoggi by Saudi intelligence operatives in Istanbul in 2018. Thus an ideological confluence over shared political hopes for the region has provided the basis for a more traditional security relationship in the light of common threats.

Moving on to Turkey's active military engagements or hard power projections, one can also observe a strong identity current shaping its foreign policy, whereby the existence of kindred ethnic groups has been used as justification for military engagement. This can be traced back to Turkish intervention in Cyprus in 1974, and has recently seen an articulation through its material support for Turkmen groups fighting in the conflicts in Syria. Turkey has provided weapons and training for Turkmen groups fighting in Syria (Ergan, 2015), and hosts the headquarters of the Syrian Turkmen Assembly in Istanbul. Turkey's support for Turkmen groups arguably unites both secular Turkish nationalists and Islamists in the country (Heller and Grimaldi, 2016), and serves as a useful legitimating narrative for President Erdoğan and the AKP in justifying their stance against the al-Assad regime in Syria. In addition, Turkey was until recently a key backer of Sunni and often also Islamist groups fighting in the Syrian conflict. This stems not only from its initial opposition to Assad (an opposition that, at the time of writing, has become accommodation with the realisation that the conflict has largely swung back in his favour), but also due to the AKP's affinity to the Muslim Brotherhood, whose pan-Islamist views chime with its own sensibilities.

While there is not room here to sketch out the intricacies and seeming intractability of the Kurdish issue in Turkish politics, it provides another example of the salient role played by identity claims in Turkish foreign policy. In discussing Turkish foreign policy during the 1990s, Robins (2014: 318) highlighted how it had often appeared 'indexed' to the issue of Kurdish ethno-nationalist radicalism. Indeed, with the recent flaring up of the conflict between the government and Kurdistan Workers' Party (PKK) following the collapse of a two-year ceasefire, this has again come to the fore as a key domestic issue. However, the wider Kurdish question also has important corollaries for Turkey's foreign policy. Turkey is nervous about a de facto Kurdish state emerging from the ruins of the Syrian civil war, and Iraqi Kurdish moves towards independence. This is compounded by the Syrian Kurdish Democratic Union Party's 
(PYD) links with the PKK, and it has been argued that the reassertion of Kurdish nationalism in northern Syria, and with it a sense of sense of growing cross-border pan-Kurdish nationalism, has contributed to the resurgence in violence in Turkey (Stein and Foley, 2016), and added some new regional dynamics to the Kurdish question in Turkey's domestic politics (Saraçoğlu and Demirkol, 2015: 318). Thus, Turkey is confronted by a key identity claim that impacts on both its domestic and foreign policies, in a case of a 'how are they not like us' type scenario which deems them as a threat. That is not to say that the notion of competing identities is doomed to conflict, however. As a counter to this, one only has to look at the, until recently, relatively harmonious relations between Turkey and the autonomous Kurdish Regional Government (KRG) in northern Iraq to see how Turkey attempts to use shape the Kurdish question in a different way. Hence one can observe the KRG's blessing for Turkey to continue with training operations for allied Iraqi militias in northern Iraq, and the development of important economic and infrastructural links between the two. This relationship has been thrown into serious turmoil, however, following the referendum on independence held in Iraqi Kurdistan in September 2017, to which Turkey was vehemently opposed.

Through its development of a foreign policy narrative based on a uniquely TurkishIslamist identity conception, Turkey has, under the AKP, sought to advance its role in regional affairs. This has come at the expense of its relations with Europe, and at the time of writing EU accession talks are firmly on ice. Özdamar (2016) has highlighted how the AKP began to institute a change in its foreign policy role conception from 2009, where it began to take a more activist stance on Middle East issues, starting with its opposition to Israel's campaigns in Gaza. From this point it sought to enact new roles such as 'regional leader', 'protector of the oppressed' and 'leader of the Muslim world', as the AKP sought to promote leadership and ties with populations across the region that were religiously and culturally close to the AKP electorate - roles which were met with domestic contestation among various sections of the Turkish polity (Özdamar, 2016: 94-5).

Since the end of the Cold War, Turkish foreign policy has been made with reference to shared identities that reach beyond its borders, utilising identity claims based on common cultural heritage. This can be seen in the attempts to develop a common Turkish cultural space following the collapse of the Soviet Union, and in continued efforts to promote Turkish culture in Turkic countries and regions, and in its material support provided to Turkmen in Syria and Iraq. Thus, cultural ties, based on a shared, transnational identity are used as a vector to further Turkish influence, and in some cases, engage militarily as with the latter. Since coming to power, and particularly since 2009, the AKP have added an Islamic element to its foreign policy thinking that has seen it seek to carve out a leadership role among Sunni Muslim communities, illustrated in its support for the Syrian opposition in that country's civil war. This is borne of sense of civilisational inheritance that comes from its historical standing in the region, and thus a Turkish-Islamist narrative is utilised for the pragmatic and strategic reasons that Barnett (2002: 68) argues are a key feature of identity-based narratives used in foreign policy. It shows how particular ideas of culture and civilisation may be (re)constructed through the communication of a strategic foreign policy narrative (Miskimmon et al, 2013: 183), which Turkish policy makers feel gives them a certain strategic advantage among the communities and networks targeted by and cultivated through their foreign policies. 
As another key regional state with leadership aspirations, Iran has also sought to make use of identity claims in its foreign policies. The earliest manifestation of this came in the early years of the Islamic Republic following the revolution in 1979, manifesting itself in the patronage of Hezbollah in Lebanon and support for Shi'i communities across the Muslim world. It is in these early efforts that one can see a narrative emerging of support for oppressed groups that chimed with revolutionary Iran's first leader Khomeini. Drawing on Shi'ism's themes of injustice, Khomeini propagated an 'Islam whose standard-bearers are the bare-footed, oppressed and poor people of the world' (Khomeini, 1989: 204). This is also forms part of the Islamic Republic's constitutionally-defined foreign policy objectives, thus further embedding core revolutionary aims into its foreign policy outlook, as exemplified in the following 'state goal' taken from the Islamic Republic's constitution, namely 'framing the foreign policy of the country on the basis of Islamic criteria, fraternal commitment to all Muslims, and unsparing support to the freedom fighters of the world' (Article 3.16 of Constitution of the Islamic Republic of Iran. ${ }^{4}$ This was very much in keeping with a 'bastion of revolution' type role, as Iran sought to actively export its revolutionary ideals.

Thus, what semblance of cultural diplomacy there was coming from Iran in the 1980s was framed in terms of exporting the revolution. Nevertheless, the new Islamic Republic of Iran's attempts to preach Islamic universalism were arguably undermined by its particularistic Shi'i and Iranian nature (Wastnidge, 2015), though Jafarpanahi and Mirahmadi (2012) do note that this was a fertile time in terms of Iran's soft power abilities due to the strong ethical slant of Khomeini's foreign policy thinking. As the most populous Shi'i majority nation, and as centre of religious learning and theology, Iran assumes a leadership role for itself among the global Shi'i community. ${ }^{5}$ It has without doubt expanded its influence in post-Saddam Iraq as a Shi'i-led government, many of whom had formerly resided in exile in Iran, has assumed control there. Bonyads (religious foundations) such as komit-ye emdad-e imam kohmeini (Imam Khomeini Relief Foundation) and bonyad-e mostazafin (Foundation for the Oppressed) and others play an important role in building transnational religious links. ${ }^{6}$ These are further reinforced through Iranian investment in Shi'i shrine cities in Iraq and Syria, and among the Shi'i Afghan Hazara community. The Islamic Culture and Relations Organisation (ICRO) is also a key channel for cultural diplomacy initiatives (see Harsij et al, 2012; von Maltzahn, 2013; Wastnidge, 2015). It runs Iran's cultural bureaus abroad, with a particular focus on fellow Muslim countries but also operates in non-Muslim states too. It has a fairly flexible remit in terms of the outreach work and communities it targets. It is also telling that the ICRO is most active in countries with large Shi'i communities and also in fellow Persian speaking nations. In terms of the former, one can point to the highly active ICRO cultural chancellery in Beirut, which sponsors frequent cultural and artistic events in Lebanon, many of which revolve around the notion of resistance to Israel and the United States. This is a cultural projection of the Islamic Republic-sponsored idea of an 'Axis of Resistance', alongside Hezbollah and Syria. Exhibitions of revolutionary and resistance art are commonly held under ICRO auspices in Lebanon, most notably the recent hosting of a resistance art exhibition at the Beirut headquarters of UNESCO in February, $2017 .^{7}$ Though less explicitly tied to religious or ethnic identity, the cultivation 
of 'resistance culture' serves as a common cultural thread binding Iran, Syria and Lebanese Shia, and finds its manifestation in the above cultural initiatives. This is a re-purposing of the revolutionary vanguard role that Iran cultivated in the early years of the Islamic Republic, with Iran crafting a role that sees itself constituting the hub of resistance to Israeli and US policies in the region. The resistance narrative feeds into many aspects of its foreign policy, in terms of its cultural diplomacy activities and military engagements in the Middle East.

Iran also is acutely aware of the dangers of sectarianism, and as such its foreign policy makers have historically sought to pitch its message in universalistic terms (Akbarzadeh and Barry, 2016), and as a model of religious democracy to be emulated. This was key in its approach towards the Arab Uprisings, ${ }^{8}$ where Iran sought to promote the uprisings taking place across the region as a form of 'Islamic Awakening' realising a new phase in the Islamic Revolution, and also as a useful way of muting the perceived influence of Iran's Green Movement on the uprisings. ${ }^{9}$ At this level one can see the harnessing of a particular 'issue narrative' (Miskimmon et al, 2013), that saw the Islamic Republic offering rhetorical support to the uprisings, which initially looked to be deposing Western-backed autocracies across the region. Though some nuance is required in this reading, given the case of Iranian intervention in Syria as will be discussed. Also, the work of the bonyads abroad is not just Shi'i-focused, for example the komit-ye emdad has carried out notable work in Tajikistan among Sunni communities there (de Cordier, 2007), again seeking to deflect the sectarian accusation often aimed at Iran.

It should be noted, however, that Iran's cultural diplomacy has not been restricted to the Shi'i or wider religious sphere. It is in the field of presidential-led cultural diplomacy initiatives that one can observe a strong nationalist conception of identity coming to the fore. This was expressed through former president Mohammad Khatami's 'Dialogue among Civilisations' initiative, which saw a strong emphasis on civilisational inheritance and commonality as forming the basis of a kind of cultural foreign policy (Wastnidge, 2016), in which an 'Islamist-Iranian' conception of identity was key (Holliday, 2007; 2011), which, like the example of Turkey , shows how particular ideas of culture and civilisation may be (re)constructed through the communication of a strategic foreign policy narrative (Miskimmon et al, 2013: 183). Attempts at promoting civil society at home also helped improve Iran's image abroad during this period. More closely linked to this paper's focus on transnational identities, one can see a specifically Persian identity being used as a kind of vector for pursuing foreign policy objectives in fellow Persian speaking nations. Central Asia has also been a historic arena for Iranian soft power-type initiatives (Wastnidge, 2014), with an emphasis on social and cultural commonalities such as the Persian New Year Norouz and the impact of Persian language, science and literature in the region. There is, naturally, a particular focus on Tajikistan and Afghanistan. The idea of a 'Union of Persian Speaking Nations' was mooted by former President Mahmoud Ahmadinejad, in an attempt to 'reawaken common Persian bonds' (Clark, 2012), which included initiatives such as a joint TV station. However, obstacles remain in implementing the project - despite the cultural commonalities of the three states, their values, interests, tastes and state policies vary. As an example, while it is mandatory for female television presenters to wear a headscarf on Iranian state TV, such practice would not be considered the norm in avowedly secular Tajikistan (Wastnidge, 2014: 127). Cultural bonds are also a useful vector in furthering Iranian economic investment 
(both private and government) in Persian speaking parts of Afghanistan, around Herat in particular, and in Tajikistan. Thus, one can see how an identity-based, strategic foreign policy narrative acts as a way of securing Iran's material interests too, in both the economic and military spheres.

Moving on to the harder aspects of Iranian foreign policy, one can see how identity-based, societal factors in other states are an important factor in its recent military engagements in the region. This is where the religious dimension once again becomes apparent, in terms of Iran having a foreign policy role in which acting as the protector of the Shia is a key narrative - something that dates back to Iran's patronage of Hezbollah in Lebanon since the 1980s. This is a discourse that has shaped Iran's military involvement in both Syria and Iraq. Firstly, in terms of Iran's involvement in Iraq, while the primary concern is about keeping Daesh as far from its borders as possible, there is also a key religious identity consideration. The Iraqi Shi'i population is a natural audience, ally and constituency for Tehran (Esfandiary and Tabatabai, 2015: 3), and when Daesh advanced a brutal, sectarian narrative that aimed to establish an extremist Sunni caliphate, and carried out massacres against the Shia, Iran acted to protect its co-religionists. As a result, Iran committed Special Forces, and military advisors with the Islamic Republican Guard Corps' (IRGC) elite Quds Force head, Qassem Suleimani, a ubiquitous presence in field operations in Iraq.

In Syria, the Twelver Shi'i population is far smaller than Iraq, and emphasis has been instead on defending Shi'i religious sites, most notably the Sayidah Zaynab shrine in Damascus. This paper does not seek to emphasise the sectarian narrative that is currently prevailing across the region as articulated in much of the media analyses, however. Iran's involvement in these two conflicts has a strong geopolitical, strategic rationale in terms of preserving its interests and maximising its influence in both states. However, religion is utilised as strong calling card for volunteer fighters, particularly in terms of having a role to play in defending Shi'i shrines. One can also point to the channelling of Shi'i 'volunteers' from Iran's large Afghan diaspora and the alleged facilitation of Shi'i volunteers from further afield in Pakistan and Iraq (Nada, 2015), in what could be seen as a strategic appropriation of religious feeling to serve geopolitical needs. What we can observe in its involvement in both the Syrian and Iraq conflicts is the use of religious-based narratives to serve as a justification for its actions. The transnational religious linkages that Iran has fostered, particularly since the revolution, act as a useful vector for reinforcing its wider strategic aims in the region.

Iran has sought various foreign policy roles since the revolution, beginning as the 'bastion of the revolution' in its role as vanguard of revolutionary Islam following the establishment of the Islamic Republic. It tempered this following the death of Khomeini, with its abandonment of active export of the revolution, and instead focused on more pragmatic aims to re-build its shattered economy after the Iran-Iraq war. It has utilised various roles, all of which place Iran at the centre of wider transnational identities. Hence, one can observe the broad, civilisational centre role espoused by Khatami, synthesising Iran's historical and deep Islamic and Iranian identity currents, and then two similar 'metropole' type roles as a centre of Shi'ism and Persian culture. Both are articulated through strategic foreign policy narratives that emphasise Iran's role at the centre of these wider transnational identity claims, and they serve useful material objectives as well - as seen in the trade links developed in culturally proximate, Persian speaking areas of Afghanistan, Iranian investment in 
Tajikistan, and in the religious justification utilised for its involvement in the Syria conflict.

Iran uses strategic narratives at all three levels as described by Miskimmon et al (2013). Indeed, the authors of the core text on strategic narratives have used the negotiations over Iran's nuclear programme as a key example of 'narrative contestation' in international affairs (Miskimmon et al, 2013: 128-39). Applying the three-level framework, one can observe 'system narratives' (with regard to Iran's role as heading up the 'Axis of Resistance' and seeking to combat global injustices in its constitutionally-defined foreign policy objectives); 'identity narratives' (drawing on Shi'i, Persian and civilisational leadership roles); and 'issue narratives' (as seen in its response to the Arab Uprisings). As with the Turkish harnessing of wider, transnational identity claims, these strategic foreign policy narratives are utilised by the Iranian foreign policy elite to further enhance relations with co-religionist and co-ethic groups. This allows Iran to develop durable networks, based on common identities that help it in pursuing its foreign policy goals

\section{Conclusion}

The foreign policies of the two states examined in this paper have all been formulated with reference to state-led narratives of identity. Though these are synonymous with the current ruling elites' notions of what constitutes national identity, they are noteworthy for the way that they are reinforced through the context of wider identities. These are less synonymous with fixed, territorialised notions of identity, though they do of course emanate from a self-perceived 'core' or ethnic and/or religious metropole, and are more about advancing foreign policy objectives through appeals to shared identity and culture. Foreign policy and diplomacy, in the main, remains in the hands of government elites who are fully cognisant of the power of using strong identity-based narratives to their advantage in relations with other states. Their use challenges fixed notions of space and sovereignty that have typified realistinformed studies of Middle Eastern states' foreign policies.

In the foreign policy activities highlighted in this paper, one can observe a combination of hard and soft power being used. This helps in the building of a strategic narrative to justify foreign policy actions, and it also shows how soft and hard power are not necessarily mutually exclusive, in the sense that there are blurred lines between the two, as seen in the use of cultural affinities as a vector for deeper involvement economically or militarily. There is consequently a material aspect in the harnessing of such identity discourses, hence their inherent strategic nature. This has a resonance with those constituencies that are supportive of the ruling regimes in question. Therefore, it is state-led and responsive to identity factors within the states in question, showing the mutually re-enforcing nature of identity in developing strategic foreign policy narratives. For the two states examined here, there is a historical weight that contributes a strong sense of both acting as metropoles for their respective cultural spheres. However, there is not an explicit neo-imperial agenda in the sense of neo-Ottomoanism, or a nascent neo-Safavism or Persian revivalism, something that would amount to diplomatic suicide for Iran and Turkey given the baggage that this would entail. These are instead useful, malleable reference points for the states concerned. Both recognise that appealing to a wider cultural commonality or 
shared identity will serve them better than crafting a role based on asserting previous imperial might over former domains.

It is important to note concerns that such an emphasis in academic analyses could be construed as a form of neo-Orientalism, as has been argued regarding constructivisttinged efforts at analysing the politics and international relations of the Middle East (Stein, 2012). However, this paper has tried to avoid the use of a 'catch all' cultural label to groups of countries, despite the notion of cultural affinities being prominent. Rather, it has noted how a sense of distinctiveness is utilised to achieve and 'narrativise' foreign policies in both Turkey and Iran. Arguably, it is the governments of the two states examined here that are essentialising identities to serve their own aims and also reinforce their domestic legitimacy. Common identities are earmarked as a key factor external to their own states that can be used in foreign policy, and thus the question 'how are they like us?' acts as a means of cultivating networks and emphasising links with certain groups for cultural diplomacy and other initiatives. This gives the states a strong foreign policy role, insofar as they are able to develop compelling, strategic foreign policy narratives that can be used a power resource in their own right. As such, this paper has demonstrated how multiple and overlapping identities articulated at the transnational level have served as a vector in which to pursue strategic foreign policy narratives in each country's perceived sphere of cultural influence. Hence, one can see both Turkey and Iran aspiring to be regional leaders, while also perceiving themselves as centres for wider, cultural affinities, be they religious, ethnic or both. These are facilitated through multifaceted, complex networks that vary across time and space, and are responsive to regional geopolitical shifts. These wider identity claims challenge fixed, spatialised notions of identity normally associated with the nation state, and can act as a challenge to the states in which they are utilised, as well as an alliance-building tool. This feeds into the region's complex geopolitical picture, where sectarian discourses are sometimes used to further strategic aims in a time of considerable tumult.

\section{Notes}

${ }^{1}$ Candidates standing for the presidency in Iran, while popularly elected, are vetted first by Iran's Guardian Council which also has oversight of parliamentary bills. The Supreme Leader is the highest-ranking power in Iran and has the final say on all key policy issues. The Islamic Revolutionary Guards Corps act as a parallel military institution in Iran, separate from the regular armed forces. They exist to protect and preserve the Islamic Republic, and also wield considerable economic power. They report to the Supreme Leader.

${ }^{2}$ See TÜRKSOY's website:www.turksoy.org/en/turksoy/about.TÜRKSOY's members are:Azerbaijan, Kazakhstan, Kyrgyzstan, Uzbekistan, Turkmenistan, Turkey, the Turkish Republic of Northern Cyprus, and the Russian Federation's autonomous republics of Tatarstan, Bashkortostan, Altai, Sakha Yakutia, Tyva and Khakassia.

${ }^{3}$ www.yunusemreenstitusu.org/turkiye/

${ }^{4}$ Article 3.16 of Constitution of the Islamic Republic of Iran: https://faculty.unlv.edu/ pwerth/Const-Iran(abridge).pdf

${ }^{5}$ An interesting aside though - and one which shows how realpolitik calculations affect Iranian strategic thinking around soft power - is Azerbaijan. Here we have a majority Shi'i state on Iran's borders. The cultural proximity is evident in the religious and linguistic links with Iran's large Azeri-speaking minority. However, Iran is cautious of irredentist sentiment among its Azeri population - who are, by and large, well-integrated 
and prominent in all walks of life - and so balances this with a very cautious approach to its fellow Shia there.

${ }^{6}$ Those fortunate enough to have spent time in Shi'i areas of Lebanon will have noticed the prevalence of the Khomeini Foundation's charity boxes on the streets of southern Beirut and other Shi'i majority areas and cities. The infrastructure works of the Iranian Committee for the Reconstruction of Southern Lebanon are also notably festooned with flags of the Iranian Supreme Leader and Khomeini, as are numerous Iranian financed mosques. (As noted by author on research trip to Lebanon, February 2017.)

${ }^{7}$ Attended by author in recent field trip to Lebanon, February, 2017.

${ }^{8}$ For further detail on Iran's response to the Arab Uprisings, see Jones (2013).

9 The Green Movement in Iran is the protest movement that grew out of the 2009 disputed presidential elections in Iran, led by the presidential election candidates Mir-Hossein Mousavi and Mehdi Karroubi, who are currently under house arrest.

\section{Conflicts of interest}

The author declares that there is no conflict of interest.

\section{References}

Akbarzadeh, S. and Barry,J. (2016) State identity in Iranian foreign policy, British Journal of Middle Eastern Studies, 43(4): 613-29. doi: 10.1080/13530194.2016.1159541

Akcall, P. and Engin-Demir, C. (2012) Turkey's educational policies in Central Asia and Caucasia: perceptions of policy makers and experts, International Journal of Educational Development, 32: 11-21.

Ansari, A. (2006) Civilisational identity and foreign policy in Iran, in B. Shaffer (ed) The Limits of Culture, Cambridge, MA: MIT Press.

Arin, K. (2014) The new Turkey: a rival to the West in the near East, E-International Relations, www.e-ir.info/2014/06/05/the-new-turkey-a-rival-to-the-west-inthe-near-east/

Arkan, Z. and Kınacıoğlu, M. (2016) Enabling 'ambitious activism': Davutoğlu's vision of a new foreign policy identity for Turkey, Turkish Studies, 17(3): 381-405. doi: 10.1080/14683849.2016.1185943

Balc1, B. (2014) 'The Gülen movement and Turkish soft power, Carnegie Endowment for International Peace, February 4, https://carnegieendowment.org/2014/02/04/glen-movement-and-turkish-soft-power-pub-54430

Barnett, M. (1996) Identity and alliances in the Middle East, in P.J. Katezenstein (ed) The Culture of National Security: Norms and Identity in World Politics, New York: Columbia University Press.

Barnett, M. (1995) Sovereignty, nationalism, and regional order in the Arab states system, International Organization, 49(3): 479-510. doi: 10.1017/S002081830003335X

Barnett, M. (1999) Culture, strategy and foreign policy change: Israel's road to Oslo, European Journal of International Relations, 5(1): 5-36. doi: 10.1177/1354066199005001001

Batalla-Adam, L. (2012) Turkey's foreign policy in the AKP Era: has there been an axis shift?, Turkish Policy Quarterly, 11(3): 139-48.

Bilgin, P. (2015) Regional security in the Middle East - what is that we seek?, Centre for Mellemøststudier - Debate Analysis. 
Breuning, M. (1997) Culture, history, role: Belgian and Dutch axioms and foreign assistance policy, in V.M. Hudson (ed) Culture and Foreign Policy, Boulder, CO: Lynne Rienner.

Breuning, M. (2011) Role theory research in international relations, in S. Harnisch, C. Frank and H.W. Maull (eds) Role Theory Research in International Relations: Conceptual Challenges and Political Promise, London: Routledge.

Calabrase, J. (1994) Revolutionary Horizons. London: Palgrave MacMillan.

Cantir, C. and Kaarbo, J. (2012) Contested roles and domestic politics: reflections on role theory in foreign policy analysis and IR theory, Foreign Policy Analysis, 8(1): 5-24. doi: 10.1111/j.1743-8594.2011.00156.x

Cantir, C. and Kaarbo,J. (2016) Unpacking ego in role theory:Vertical and horizontal role contestation and foreign policy, in C. Cantir and J. Kaarbo (eds) Domestic Role Contestation, Foreign Policy, and International Relations, New York: Routledge.

Clark, B. (2012) Iranian foreign policy toward Tajikistan and Afghanistan during the Ahmadinejad presidency: the rising salience of Persian national identity, Journal of Central Asian E Caucasian Studies, 7(13): 73-105.

Danforth, N. (2014) Multi-purpose empire: Ottoman history in republican Turkey, Middle Eastern Studies, 50(4): 655-78. doi: 10.1080/00263206.2014.892481

Davutoğlu,A. (2001) Startejik Derinlik Türkiye'nin Uluslararası Konumu (Strategic Depth, Turkey's International Position), Istanbul: Küre.

Davutoğlu, A. (2010) Turkey's zero-problems foreign policy, Foreign Policy, 20: 740.

De Cordier, B. (2007) Shiite aid organizations in Tajikistan, ISIM Review, 19: 1-11.

Ehteshami, A. and Varasteh, M. (1991) Iran and the International Community, London: Routledge.

Ennis, C.A. and Momani, B. (2013) Shaping the Middle East in the midst of the Arab uprisings: Turkish and Saudi foreign policy strategies, Third World Quarterly, 34(6): 1127-44. doi: 10.1080/01436597.2013.802503

Ergan, U. (2015) Turkish military starts training missions in Iraq, Syria, Hurriyet Daily News, 16 March, www.hurriyetdailynews.com/turkish-military-starts-trainingmissions-in-iraq-syria.aspx?pageID $=238 \&$ nid $=79721$

Esfandiary, D. and Tabatabai, A. (2015) Iran's ISIS policy, International Affairs, 91(1): 1-15. doi: 10.1111/1468-2346.12183

Fawcett, L. (2005) Introduction, in L. Fawcett (ed) International Relations of the Middle East, Oxford: Oxford University Press.

Halliday, F. (2005) The Middle East in International Relations: Power, Politics and Ideology, Cambridge: Cambridge University Press.

Harnisch, S. (2011) Role theory: operationalization of key concepts, in S. Harnisch, C. Frank, and H.W. Maull (eds) Role Theory in International Relations: Approaches and Analyses, London: Routledge.

Harnisch, S., Frank, C. and Maull, H.W. (2011) Introduction, in S. Harnisch, C. Frank, and H.W. Maull (eds) Role Theory in International Relations: Approaches and Analyses, London: Routledge.

Harsij, H., Toyserkani, M. and Jafari, L. (2012) The geopolitics of Iran's soft power (in Persian), Political Science, 4(2): 225-69.

Heller, S. and Grimaldi, S.G. (2016) A cause for all Turks:Turkey and Syria's Turkmen rebels, War on the Rocks, http://warontherocks.com/2016/01/a-cause-for-allturks-turkey-and-syrias-turkmen-rebels/ 
Hinnebusch, R. (2005) The politics of identity in the Middle East, in L. Fawcett (ed) International Relations of the Middle East, Oxford: Oxford University Press.

Hinnebusch, R. (2014) Introduction, in R. Hinnebusch and A. Ehteshami (eds) The Foreign Policies of Middle East States, London: Lynne Reiner.

Hinnebusch, R. and Ehteshami, A. (eds) (2014) The Foreign Policies of Middle East States, London: Lynne Reiner.

Holliday, S. (2007) The politicisation of culture and the contestation of Iranian national identity in Khatami's Iran, Studies in Ethnicity and Nationalism, 8(1): 27-45. doi: 10.1111/j.1754-9469.2007.tb00106.x

Holliday, S. (2011) Defining Iran: Politics of Resistance, Farnham: Ashgate.

Holsti, K.J. (1970) National role conceptions in the study of foreign policy, International Studies Quarterly, 14(3): 233-309. doi: 10.2307/3013584

Hudson, V.M. (2005) Foreign policy analysis: actor-specific theory and the ground of international relations, Foreign Policy Analysis, 1(1): 1-30. doi: 10.1111/j.17438594.2005.00001.x

Hudson,V.M. (2014) Foreign Policy Analysis: Classic and Contemporary Theory, Plymouth: Rowman and Littlefield.

Ípek, P. (2015) Ideas and change in foreign policy instruments: soft power and the case of the Turkish international cooperation and development agency, Foreign Policy Analysis, 11(2): 173-93.

Jafarpanahi, M. and Mirahmadi, M. (2012) Elements of the Islamic Republic of Iran's soft power with an Islamic Approach (in Persian), Journal of Political Knowledge, 4(2): 105-22.

Jones, P. (2013) Hope and disappointment: Iran and the Arab Spring, Survival, 55(4): 73-84. doi: 10.1080/00396338.2013.823033

Kassimeris, C. (2010) Turkey's foreign policy options: Europe, the USA or Central Asia?, Contemporary Politics, 16(3): 321-36. doi: 10.1080/13569775.2010.501653

Kaya, A. (2013) Yunus Emre cultural centers: the AKP's Neo-Ottomanism and Islamism, Perspectivesi, 5: 56-60.

Kiper, C. (2013) Sultan Erdoğan:Turkey's rebranding into the new, old Ottoman Empire, The Atlantic, 5 April, http://theatlantic.com/international/archive/2013/04/sultanedrogan-turkeys-rebranding-into-the-new-old-ottoman-empire/274724/

Khomeini, R. (1989) Sahifeh-ye Imam Khomeini, jeld-e dovvom (Anthology of Imam Khomeini's Works, Volume Two), Tehran:The Institute for Compilation and Publication of Imam Khomeini's Works.

Mattern, J.B. (2005) Why soft power isn't so soft: representational force and the sociolinguistic construction of attraction in world politics, Millennium, 33(3): 583-612. doi: 10.1177/03058298050330031601

Miskimmon, A., O’Loughlin, B. and Roselle, L. (2013) Strategic Narratives: Communication Power and the New World Order, New York: Routledge.

Nada, G. (2015) Iran's growing toll in Syria, The Iran Primer - United States Institute of Peace, http://iranprimer.usip.org/blog/2015/oct/26/iran\%E2\%80\%99sgrowing-toll-syria

Nye, J.S. (2004) Soft Power: The Means to Success in World Politics, New York: Public Affairs.

Oğuzlu, T. (2007) Soft power in Turkish foreign policy, Australian Journal of International Affairs, 61(1): 81-97. 
Öztürk, B. (2013) Turkey's new foreign policy: a manifestation of Neo-Ottomanism?, EuroAsia News: Analysis, http://www.euroasianews.com/analysis-turkeys-newforeign-policy-a-manifestation-of-neo-ottomanism/

Özdamar, Ö. (2016) Domestic sources of changing Turkish foreign policy toward the MENA during the 2010s, in C. Cantir and J. Kaarbo (eds), Domestic Role Contestation, Foreign Policy, and International Relations, New York: Routledge.

Peimani, H. (1998) Regional Security and the Future of Central Asia - The Competition of Iran, Turkey, and Russia, Westport, CT and London: Praeger.

Raekel, E. (2003) Paradigms of Iranian policy in Central Eurasia and beyond, Perspectives on Global Development and Technology, 2(3-4): 549-71. doi: 10.1163/156915003322986398

Ramazani, R.K. (1992) Iran's foreign policy: both north and south, The Middle East Journal, 46(3): 393-412.

Ramazani, R.K. (2004) Ideology and pragmatism in Iran's foreign policy, The Middle East Journal, 58(4): 1-11. doi: 10.3751/194034604783997123

Robins, P. (2014) The foreign policy of Turkey, in R. Hinnebusch and A. Ehteshami (eds), The Foreign Policies of Middle East States, London: Lynne Reiner.

Roselle, L., Miskimmon, A. and O’Loughlin, B. (2014) 'Strategic narrative: a new means to understand soft power, Media, War \& Conflict, 7(1): 70-84. doi: $10.1177 / 1750635213516696$

Saraçoğlu, C. and Demirkol, Ö. (2015) Nationalism and foreign policy discourse in Turkey under the AKP rule: Geography, history and national identity, British Journal of Middle Eastern Studies, 42(3): 301-19.

Seufert, G. (2012) Foreign Policy and Self-Image: The Societal Basis of Strategy Shifts in Turkey: SWP Research Paper, Berlin: Stiftung Wissenschaft und Politik/German Institute for International and Security Affairs.

Shaffer, B. (2006a) Introduction, in B. Shaffer (ed), The Limits of Culture, Cambridge, MA: MIT Press.

Shaffer, B. (2006b) The Islamic Republic of Iran: is it really?, in B. Shaffer (ed), The Limits of Culture, Cambridge, MA: MIT Press.

Stein, E. (2012) Beyond Arabism vs. sovereignty: relocating ideas in the international relations of the Middle East, Review of International Studies, 38(4): 881-905. doi: 10.1017/S0260210511000465

Stein, A. and Foley, M. (2016) The YPG-PKK connection, Atlantic Council MENA Source Analysis, www.atlanticcouncil.org/blogs/menasource/the-ypg-pkkconnection

Taşpinar, Ö. (2008) Turkey's Middle East policies: between Neo-Ottomanism and Kemalism, Carnegie Papers, 10: 1-28.

Telhami, S. and Barnett, M. (2002) Introduction, in S. Telhami and M. Barnett (eds), Identity and Foreign Policy in the Middle East, New York: Cornell University Press.

Thies, C. (2010) Role theory and foreign policy, in R.A. Denemark (ed) The International Studies Encyclopaedia, Oxford: Blackwell.

Thies, C. (2012a) International socialization processes vs. Israeli national role conceptions: can role theory integrate IR theory and foreign policy analysis?, Foreign Policy Analysis, 8(1): 25-46. doi: 10.1111/j.1743-8594.2011.00170.x

Thies, C. (2012b) The roles of bipolarity: a role theoretic understanding of the effects of ideas and material factors on the Cold War, International Studies Perspectives, 14(3): 269-88. doi: 10.1111/j.1528-3585.2012.00486.x 
Thies, C. and Breuning, M. (2012) Integrating foreign policy analysis and international relations through role theory, Foreign Policy Analysis, 8(1): 1-4. doi: 10.1111/j.17438594.2011.00169.x

von Maltzahn, N. (2013) Iran's cultural diplomacy, in C. Therme, H.E. Chehabi and F. Khosrokhavar (eds), Iran and the Challenges of the Twenty-first Century: Essays in Honour of Mohammad-Reza Djalili, Costa Mesa, CA: Mazda.

von Schwerin, U. (2018) Erdoğan seizes the school initiative, Qantara, 28 November, https://en.qantara.de/content/turkey-and-the-gulen-movement-erdogan-seizesthe-school-initiative

Walker, S.G. (1987) Role theory and foreign policy analysis: an evaluation, in S.G. Walker (ed) Role Theory and Foreign Policy Analysis, Durham, NC: Duke University Press.

Wastnidge, E. (2014) Pragmatic politics' Iran, Central Asia and cultural foreign policy, Central Asia and the Caucasus, 15(4): 119-30.

Wastnidge, E. (2015) The modalities of Iranian soft power: from cultural diplomacy to soft war, Politics, 35(3-4): 364-77. doi: 10.1111/1467-9256.12084

Wastnidge, E. (2016) Diplomacy and Reform in Iran: Foreign Policy under Khatami. London: I.B. Tauris.

Wastnidge, E. (2019) Imperial grandeur and selective memory: re-assessing neoOttomanism in Turkish foreign and domestic politics, Middle East Critique, 28(1): 7-28. doi: 10.1080/19436149.2018.1549232

Wendt,A. (1992) Anarchy is what states make of it: the social construction of power politics, International Organisation, 6(2):391-425. doi: 10.1017/S0020818300027764

Wendt, A. (1999) Social Theory of International Politics, Cambridge: Cambridge University Press. 